\title{
Research of the Impact of the MOOCs on Business English Teaching of Vocational Schools
}

\author{
Pei Song ${ }^{1}$ \\ ${ }^{1}$ Jiangxi College of Foreign Studies, Nanchang, Jiangxi, 330099 \\ 59624917@163.com
}

Keywords: MOOCs; Higher Vocational College; Major Construction; Problems

\begin{abstract}
Moocs domestic and foreign educators to become a hot topic Business English courses are also exploring how to Mu applied to teaching. It introduces the meaning and characteristics of Moocs, as well as business English major, and using SWOT analysis, from the internal strengths and weaknesses and external opportunities and threats analysis for business English teaching professional $\mathrm{Mu}$, then build its strategy SWOT matrix analysis. Despite the weaknesses and threats, business English lessons professional Mu application is still a great advantage and opportunity, so avoid weaknesses, and vigorously promote Mu Business English Course and platform become the only way.
\end{abstract}

\section{Introduction}

Mooc Division (MOOCs) stands for Massive Open Online Courses, namely large-scale network open courses, is designed to unlimited participation in the network and open access online courses. In addition to traditional course materials (such as video, reading material and exercises) Moocs also provides an interactive user forum to help students and teachers to build a community, is a technology developed in recent years of distance education. That is to emphasize not only the Moocs learning content and learners, but also emphasizes a teacher and students together on a topic set up internet. "Moocs" concept is a Canadian scholar Dave Cormier and Bryan Al-exander made in 2008. Name reflects the characteristics of Mu Moocs: massive, many refers both to the number of learners, but also refers to the diversity of courses and activities; open, which is an important condition for the Moocs distinction from other online courses, $\mathrm{Mu}$ Open lesson refers to any learner can equally participate $\mathrm{Mu}$ lesson to learn, there is no source of information, education levels, learning environment, learning time and geographical constraints; online learning, includes not only online access to information, including online community companion between collaboration and evaluation.

Business English definitions may be narrower width. The narrowest definition is "only with business English can be called directly related to Business English." Slightly wider definition is "all business-related fields (economics, management, law, etc.) are considered English Business English." Broadest definition is "to all my personal relationship beyond the English are business English." Business English program aims at training with a solid basic skills in English, broad international perspective, reasonable international business knowledge and skills, to master the basic knowledge and theory of economics, management and law and other related disciplines, with high humanities and intercultural communication and communication skills, be able to engage in business, trade, management, finance, foreign affairs and other work of complex English talents in an international environment with English. Business English language teachers not only have professional knowledge, but also have basic knowledge of business professionals

\section{SWOT Analysis of MOOC Application on Business English Teaching}

Moocs platform provides teaching resources worldwide first-class university, can provide learning resources for inter-institution postgraduate students and minor second degree students, provide a way for the inter-school credit recognition. Moocs full use of means of animation, video, micro courses, embedded quizzes, adding RSS Feed Forum, both in line with Business English 
professional training mode, and also enhance the students' practical abilities and skills. Process evaluation. Teachers can fully understand the learning process, including on-line time, visits, exchange times, learning progress, test scores and other online. Ubiquitous learning. Students can break through the restrictions of time and place, online learning anytime, anywhere on your mobile device; you can also manage the entire task fragmentation, improve knowledge of permeability and time efficiency. Self-learning. Students are free to grasp the depth of learning content and learning progress learning.

A course needs teachers collaboratively over: before the course start speaker teachers spend an average of 100 hours lesson planning, you need at least one assistant, courses should spend eight hours a week online Q \& A. Business English courses for less. Business English Major emerging as interdisciplinary specialty produce, have not formed a complete course on Moocs platform group. Students can only reference English professional foundation courses and financial, management courses, the lack of relevance. Business English textbooks there is a systematic lack of timeliness, practicality is not strong, the concept is unclear, the lack of teaching resources and other issues, which restricts the construction Moocs platform. Many teachers still do not understand the Moocs, holding classes for Mu fear and contradictory attitude; at the same time, the pressure for research and titles, but also the teachers Mu lesson sidelines. Stanford, MIT dropout rates Moocs and UC Berkeley carried out up to $95 \%$, showing that students' consciously active learning alone is not enough.

Emerging dynamic and professional potential. From the outset of Business English Major established, it is committed to developing the compound and applied talents for the traditional English teaching energized. New professional building more resources, more attention practice new teaching methods, to create a favorable external conditions for the Moocs promotion. Policy support, invested considerable. In March 2012 the Ministry of Education, the construction of educational information system covering urban and rural schools at all levels, and promote the sharing of universal quality education resources, information technology and education to promote the depth of integration, to achieve educational ideas, concepts, methods and means comprehensive innovation. Abroad has been more mature platform for reference. Moocs ubiquitous, personalized, diversity, traditional teacher-centered classroom will be very difficult for them to produce attractive. The impact on the local ordinary class elite schools. By Moocs, students can break limit access to world-class schools curriculum time and place even obtain credit, which is bound for the local ordinary schools have a huge impact. Changing the role of teachers. In the traditional classroom model, the teacher is the main center and the classroom imparting knowledge, teachers in Mu lesson for students to explore the changing role of guide and facilitator, authority will be subject to certain challenges.

\section{The Changed of Study Method Leaded by MOOC}

$\mathrm{Mu}$ development courses will also be students how to learn, how to learn effectively have a significant impact. Past the classroom, students can only listen to the speaker professor lectures, but now you can find numerous online courses online. More importantly, they do not need to hear the end from the beginning, but you can skip that they have mastered the content, repeat play yet difficult to understand or grasp the part. And now a lot of online courses not only automatically reply learners problem, they can also offer help according to the learner's questions. Moocs of widely popular, so that people realize that technology, network as well as the importance of fast and convenience in education at the same time, will be more dependent on technology, more network-based learning methods will appear. For example, some schools will learn to combine online and offline learning, there have been a teaching method called the "flipped classroom", which called for students after class or at home watching online video lessons, complete the appropriate learning programs, mainly with the classroom teacher interact and solve problems encountered online and offline. This is actually a combination of traditional and modern, but its effect is much better than traditional teaching. According to the San Jose State University and 
Education Online (edX) in the fall of 2012 tests found that the new teaching methods of the past traditional classroom teaching only $55 \%$ pass rate increased to $91 \%$.

At present, with the widely popular Moocs universities, many teachers are facing such an embarrassing problem that if the teaching were able to see first-class brand-name colleges and universities, Professor Mu lesson on the network, then the student for us The classroom will be there are many picky. Or they simply see no need to heat or cold day trek against the wind came inside our classroom learning. You can house in the bedroom, sitting in front of the computer at any time to turn on the computer to see the masters of their courses. Faced with this situation, we can not be avoided, based on this, teachers also need to be adjusted accordingly. For example, some institutions had already begun to try to allow students to take advantage of after-school time over the network to complete the prescribed part of the study. Students can choose your favorite well-known professors tracking study. Teachers' classroom time for answering questions, doubts, in order to improve teaching effectiveness. In this way, so that students receive the most first-class as explained in the schools where professors, and then by teaching assistants careful guidance, we can say virtually make teaching level in this course a new level.

Of course, open learning is not necessarily the institutions are willing to accept. Many colleges and universities have begun to try their own current record Moocs. After all, for teaching, it is not necessarily the quality of teaching in schools is necessarily superb, although knowledgeable professors, not teaching but it must be first class. Furthermore, the professional has practical features, some courses may not be adapted to the professional school. Therefore, many institutions see the advantages and characteristics of Moocs. Actively guide teachers build self-confidence, his classroom recorded, build quality curriculum Moocs. Of course, in this process, the teacher's role has undergone a lot of changes, it also has a different job content. The traditional teaching of teachers is as long as their lesson planning, teaching, correcting homework on it. Today, teachers look like the director, before teaching students to take into account the status of teachers in the state, even to communicate angle, sound, lighting problems and camera crews. The curriculum is also designed to be concise, classic, based on this, to develop a course of Moocs is by no means a man's work, has become a whole work of the teaching team. Moocs is changing the teacher's teaching, but also changed the process of reflection after-school teachers. Traditional teaching, teachers would be based on after-school classroom after school to reflect the feeling, but in which Moocsroom Teachers can watch students' classroom reflects this observation will be more detailed and more accurate than observed in the classroom, help teachers more clearly find teaching problems, students receiving state. Meanwhile, Moocs is a public dissemination of courses, students, experts, peers can give lessons, which is also a teacher and help promote.

\section{Conclusion}

Mooc arrives of the emerging class of business English teaching both opportunities and challenges. Lesson of $\mathrm{Mu}$ neither complacent and refuse new things, we can not blindly worship. Moocs cannot completely replace the business English teaching, and how to use the Moocs, the real benefit of teaching business English, business English will be the direction of professional effort.

\section{References}

[1] Liu Fagong. China from Scratch Business English Subjects. Western World, 2009 (6): 10-16.

[2] Masters K. A Brief Guide to Understanding Moocs. The Internet Journal of Medical Education, 2011, 1(2).

[3] Weihrich H. The Tows Matrix: A Tool for Situational Analysis. Long Range Planning, 1982, 15(2): 54-66.

[4] Meyer R. What It's Like to Teach A Mooc (And What The Heck'S A Mooc?).[De/Ol].. Http://Tinyurl.Com/Cdfvvqy, 2012. 